\title{
The Invention and Demonisation of an Ascetic Heresiarch: Philoxenus of Mabbug on the 'Messalian' Adelphius
}

\author{
by SOPHIE LUNN-ROCKLIFFE \\ Peterhouse, Cambridge \\ E-mail:sjl39@cam.ac.uk
}

In a letter to the monk Patricius, Philoxenus told a cautionary tale about the downfall of the monk Adelphius. He was said to have accepted a Satanic vision of the Holy Spirit, abandoned ascetic labour and become the founder of the heresy of the 'Messalians'. This article places Philoxenus' account against the longer background of the invention of 'Messaliainism', and in particular of Adelphius as Messalian heresiarch. It shows how Philoxenus drew on traditions about monks receiving Satanic visions found in ascetic literature. It also demonstrates that Philoxenus' story reflected polemical claims that the Messalians, like other heretics, were inspired by demons and Satan.

I

$\mathrm{n}$ the late fifth or early sixth century, Philoxenus, miaphysite bishop of Hierapolis-Mabbug, wrote a long letter in Syriac replying to Patricius, a monk at Edessa. ${ }^{1}$ Patricius' original letter does not survive, but it

$\mathrm{CSCO}=$ Corpus Scriptorum Christianorum Orientalium; GCS $=$ Die Griechischen Christlichen Schriftsteller; $P G=$ Patrologia Graeca; $P L=$ Patrologia Latina; $P O=$ Patrologia Orientalis; $\mathrm{SC}=$ Sources Chrétiennes; Scri. Syri $=$ Scriptores Syri

An early version of this article was presented at the 2010 annual meeting of the North American Patristics Society; my thanks to my co-panellists and audience for extremely helpful discussion and suggestions. I am also very grateful to Chip Coakley for teaching me Syriac and introducing me to the wealth of Syriac literature, which has made the research for this article possible.

${ }^{1}$ Philoxenus' letter survives in two Syriac recensions, one long and one short. The longer Syriac text, which is older, is studied in this article. It was edited by René 
appears that he had questioned the need for ceaseless ascetic labour as a route to contemplation. Philoxenus responded by exhorting Patricius to follow his particular interpretation of Evagrian ascetic practice, illustrated by a number of stories about both successful and failed monks; among the notable failures was Adelphius, described as the founder of the heresy of 'the praying ones' (דى (ת) 'Messalians'). According to Philoxenus, Adelphius had spent time in Edessa, and then travelled to the Sinai and Egypt with Julian Saba and met various desert Fathers, including Antony the Great, before moving back to Edessa to devote himself to a life of ascetic hardship and continual prayer. However, vainglory burned in him, and when he received a Satanic vision in the form of a light which claimed to be the Holy Spirit, he failed to act with appropriate humility and reject it; instead, he worshipped it, and was filled with demonic hallucinations which convinced him that he no longer needed to exert himself in ascetic labours. Adelphius subsequently attracted a large following of monks who were condemned and chased out of Edessa, and Philoxenus reported that in his own day they were found in the monasteries of Iconium. ${ }^{2}$

This vivid story has no parallels in other surviving ancient accounts of Adelphius. The few scholars who have commented on it have variously doubted its credibility, and mined it for new information. ${ }^{3}$ However, this article is not principally concerned to retrieve fresh details about an 'historical' Adelphius from Philoxenus' account. Rather, it seeks to establish the influences on, sources for, and resonances of Philoxenus' anecdote, and to read it as part of a longer process of the invention and demonisation of the so-called 'Messalian' heresy. It thus builds on the persuasive arguments of scholars like Columba Stewart and Daniel Caner that those first stigmatised as Messalians were in fact far from cohesive in their identity, beliefs and

Lavenant from eight manuscripts: 'La Lettre à Patricius de Philoxène de Mabboug', PO $\mathrm{xxx} / 5$ (1963), $725^{-894}$. The shorter recension has still not been edited, but appears attributed to different authors - in two manuscripts, MS Vat. syr. 125, Biblioteca

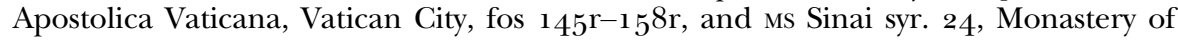
St Catherine, Mount Sinai, fos 147v-164v; on these see Grigory Kessel, 'Sinai syr. 24 as an important witness to the history of some Syriac ascetic texts', in Françoise Briquel Chatonnet and Muriel Debié (eds), Sur les Pas des Araméens chrétiens: mélanges offerts à Alain Desreumaux, Paris 2010, 207-18. The shorter recension was translated into Greek and circulated under the name of Isaac of Nineveh. It was edited by Angelo Mai in Nova patrum bibliotheca, Rome 1871, viii. 157-87. On all these texts see David Michelson, 'A bibliographic clavis to the works of Philoxenus of Mabbug', Hugoye xiii/ 2 (2010), 273-338 at pp. 304-5.

${ }^{2}$ Philoxenus, Letter to Patricius 108-10, Lavenant, 'La Lettre', $85^{\mathrm{O}-5}$.

3 For example, Columba Stewart, is sceptical about Adelphius' Egyptian connection: Working the earth of the heart: the Messalian controversy in history, texts and language to $A D 43 I$, Oxford 1991, 39-41. Klaus Fitschen, on the other hand, is open to it: Messalianismus und Antimessalianismus: ein Beispiel ostkirchlicher Ketzergeschichte, Göttingen 1998, 93-4. 
practices beyond an ascetic drive and an origin in Syro-Mesopotamia, and were bestowed a group identity in large part by their opponents. ${ }^{4}$ It also draws on the current scholarly consensus that heresies in late antiquity were largely constructed through polemical processes of labelling and 'othering'. 5

The first section of this article surveys the changing presentation of Adelphius by anti-Messalian sources, placing Philoxenus' story in a longer process of the invention of a heresy. Initially, in the fourth and fifth centuries, he was presented as a spokesman for his group and one of its several early leaders; by the sixth century, he had emerged as a founder figure in the Philoxenian vein. The invention of Adelphius as sole 'heresiarch' is argued to be part of a long-standing heresiological tradition of constructing 'genealogies' and founders of heresies. The second part demonstrates a range of striking similarities between Philoxenus' story about the fall of Adelphius, and cautionary tales about monks in a range of ascetic literature from the apophthegmata patrum ('sayings of the Fathers') to Palladius' Lausiac history and Evagrian treatises. Whether Philoxenus himself was responsible for this confection, or drew on an existing tradition, the echoes of ascetic tales in his portrait of Adelphius suggest that it was more 'imagined' than historical. The final section proposes that Philoxenus' story reflected hostility to practices long attributed to the Messalians, such as the possibility of seeing any person of the Trinity with bodily eyes. It also demonstrates how this story focused in the person of Adelphius long-standing ideas that the Messalians had misinterpreted their state of ecstatic inspiration as evidence of the indwelling of the Holy Spirit, when they were in fact possessed by demons. Overall, Philoxenus' tale is placed in a longer process of the invention of Adelphius as a Messalian heresiarch, and of the demonisation of that heresy.

\section{Adelphius as heresiarch}

At the opening of his account of Adelphius' ascetic downfall, Philoxenus identified him as the sole 'inventor' (sحسن) of the Messalian heresy, and he concluded his narration by explaining that after Adelphius had

4 Stewart, Working the earth, 234-40; Daniel Caner, Wandering, begging monks: spiritual authority and the promotion of monasticism in late antiquity, Berkeley 2002, 83-104; Marcus Plested, The Macarian legacy: the place of Macarius-Symeon in the eastern Christian tradition, Oxford 2004, 16-27.

5 Eduard Iricinschi and Holger Zellentin, 'Making selves and others: identity and late antique heresiologies', in Eduard Iricinschi and Holger Zellentin (eds), Heresy and identity in late antiquity, Tübingen 2008, 1-27; Averil Cameron, 'How to read heresiology', Journal of Medieval and Early Modern Studies xxxiii (2003), 471-92. 
given in to Satan, he had become the 'leader' or 'chief' (rwi) of the heresy. ${ }^{6}$ However, the very names applied to these heretics in earlier sources suggest that they did not originally have a clear founder, and were rather identified by their own behaviour. ה in Syriac, transliterated into Greek variously as $\mu \alpha \sigma \sigma \alpha \lambda ı \alpha v o i ́, \mu \varepsilon \sigma \alpha \lambda ı \alpha v o i ́$ and $\mu \varepsilon \sigma \sigma \alpha \lambda ı \alpha v o i$,

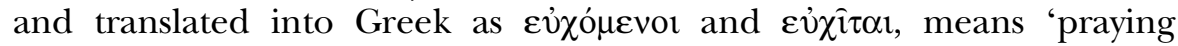
ones'. It was a hostile term, characterising the group by one of their supposed practices, perpetual prayer. Similarly, the labelling of this group as غ่v$\theta 0 v \sigma i \alpha \sigma \tau \alpha i$ ('possessed ones') evoked a behaviour rather than an origin (a notion to which we will later return). 7 The first surviving polemics against the Messalians, which date from the late fourth century, also show that this was not a heresy whose identity was closely linked to a named leader. In the very structure of his Hymn 22 against heresies, Ephrem implicitly distinguished between heresies associated closely with their founder, and those identified by their beliefs or behaviour: stanza 3 lists heresies from Valentinus to Mani which all took their names from their founders, while stanza 4 reels off a range of heresies - ending with the דكى which were all characterised by their errors. ${ }^{8}$ In his Panarion, an encyclopedic 'medicine-chest' of heresies, Epiphanius explicitly voiced his

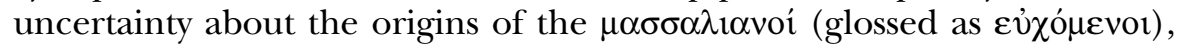

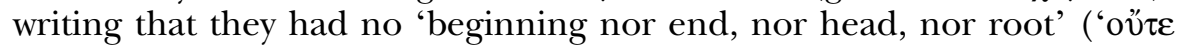

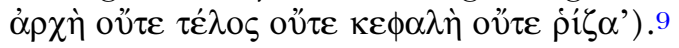

Adelphius is first mentioned among multiple leaders or founders of 'Messalianism' in polemical texts of the mid-fifth century. In discussions of the heresy in his Ecclesiastical history and Compendium of heretical fables, Theodoret of Cyrrhus seems to have drawn on accounts of anti-Messalian synods at Antioch and Side in the late fourth century, at the first of

${ }^{6}$ Philoxenus, Letter to Patricius 108, 1 10, Lavenant, 'La Lettre', 85 o, 854 .

7 On the various names for the group see Jean Gribomont, 'Le Dossier du Messalianisme', in Jacques Fontaine and Charles Kannengiesser (eds), Epektasis: mélanges patristiques offerts au cardinal Jean Daniélou, Paris 1972, 611-25 at pp. 620-1.

8 Ephrem, Hymn 22 Against Heresies, ed. Edmund Beck, in Heiligen Ephraem des Syrers Hymnen contra haereses, CSCO clxix / Scr. Syri lxxvi.78-86 at $78^{-} 9$. See Gribomont, 'Le Dossier', 61 2; Fitschen, Messalianismus, 19-21; and Stewart, Working the earth, 15-18. I differ from Stewart (p. 15 n. 6) in seeing an organisational principle at work in this hymn; although stanza 4 admittedly includes heresies which took their names from their founder, it also includes three - Borborians, Cathars and Messalians - which did not, and characterises all nine heresies by their error. Furthermore, the next two hymns in the series, 23 and 24 , circle around the issue of heresies taking their names from their founder.

9 Epiphanius, Panarion 80.3.2, ed. Karl Holl, rev. Jürgen Dummer, in Epiphanius Werke, Berlin 1985, iii. 487. See Gribomont, 'Le Dossier', 613-14; Fitschen, Messalianismus, 21-4; and Stewart, Working the earth, 18-24. Stewart (p. 18) points out that Epiphanius' puzzlement about the Messalians is in part because, 'unlike so many groups, the Messalians were not named after a founder or controversialist'. 
which Adelphius appeared. ${ }^{\circ}$ He listed the men who were 'founders'

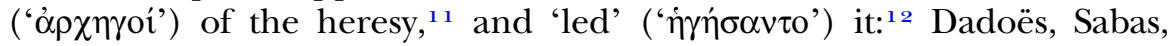
Adelphius, Symeon, Hermas and others. ${ }^{13}$ The order of the names listed is different in the two works, but neither places Adelphius first. However, both texts foreground the role of the elderly Adelphius at the Synod of Antioch, recounting how he was tricked by Flavian, bishop of Antioch, into giving an account of the group's beliefs and practices which secured the condemnation of him and his fellows. In the Compendium, he is even said to have 'led' ('îعiтo') the heresy. ${ }^{14}$

The central role of Adelphius at Antioch is confirmed by later accounts which themselves drew on earlier records. Stewart argues that the 'memoranda written against Adelphius' mentioned in a treatise by Severus of Antioch refer to a record of the decisions of the Synod of Antioch; this suggests that, in memory at least, the synod focused its ire on Adelphius. ${ }^{15}$ Photius' early ninth-century Bibliotheca, an enormous collection of reports and summaries of earlier texts and documents, includes an account of the Synod of Antioch which lists the various 'begetters'

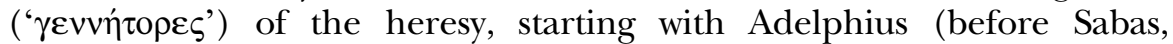
Eustathius, Dadoës and Symeon). Photius' account also emphasised Adelphius' role at Antioch by focusing on his personal repentance and the council's condemnation of 'Adelphius and those with him'

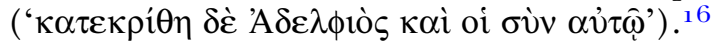

Adelphius eventually gave his name to a heresy. In a letter of the early sixth century Philoxenus' ally Severus of Antioch described Lampetius (who had recently been condemned at the Synod of Comana) as 'infected with the heresy of Adelphius', and referred to his followers as a 'flock of

${ }^{10}$ On the synods see Gribomont, 'Le Dossier', 614-16; Stewart, Working the earth, 245; and Fitschen, Messalianismus, 25-37. On Theodoret and his sources see Stewart, Working the earth, 25-9.

11 Theodoret, Ecclesiastical history 4.1 1, ed. and trans. Pierre Canivet, SC dxxx, Paris $2009,222$.

${ }_{12}$ Theodoret, Compendium of heretical fables 4.11 , in M. Kmosko, Liber graduum, Patrologia Syriaca iii (1926), p. cc.

13 Gribomont, 'Le Dossier', 615 $5^{-16}$; Stewart, Working the earth, 25-9; Fitschen, Messalianismus, $25^{-9}$.

${ }_{14}$ Theodoret, Compendium 4.11, Kmosko, Liber graduum, p. cxcix.

15 Stewart, Working the earth, 34-6 at p. 35, citing Severus of Antioch, Contra additiones Juliani from René Draguet, Julien d'Halicarnasse et sa controverse avec Sévère d'Antioche sur l'incorruptibilité du corps du Christ, Louvain 1924, 129-31.

${ }^{16}$ Photius, Bibliotheca 52, in Kmosko, Liber graduum, pp. cclii-cclxi at p. ccliv; Gribomont, 'Le Dossier', 614; Stewart, Working the earth, 29-34; Fitschen, Messalianismus, 25-34. Gribomont (p. 614), locates the origin of Photius' canonical collection in sixth-century miaphysite milieux. 
Adelphians' ${ }^{17}$ In about 600 Timothy of Constantinople provided a rather jumbled list of names for the heretics: 'Marcianists and Messalians and Euchites and Choreuts and Lampetians and Adelphians and Eustathians'. ${ }^{18}$ Before his summary of the Synod of Antioch, Photius mentioned in passing the acts of the Synod of Side, described as held 'against the heresy of the Messalians, that is to say, Euchites or Adelphians'

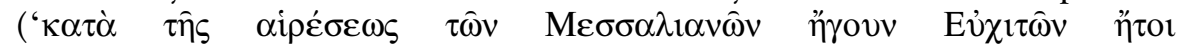
'A $\left.\delta \varepsilon \lambda \phi 1 \alpha v \hat{v} v^{\prime}\right) ; 19$ Photius may have been reporting the contents of the manuscript before him, in which case 'Adelphians' belongs to an older tradition, or it may be his own gloss on 'Messalians', explaining an unfamiliar group by recourse to a more familiar one. ${ }^{20}$

At some point between the fourth and sixth centuries, then, Adelphius came to be known not just as a leader of and spokesman for the Messalians, but as their founder. Philoxenus' passing prefatory remark to

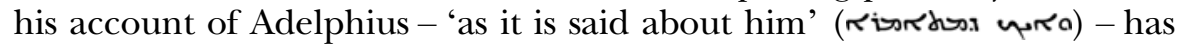
been read as a nod to his oral or other sources, but no single Vorlage for his account can be identified. ${ }^{21}$ His sources would likely have been in Syriac, given the apparent limitations of his Greek, ${ }^{22}$ and Philoxenus' hostility to Theodoret means that he cannot have taken inspiration from either of his works. ${ }^{23}$ However, since most of the texts examined above themselves drew on earlier sources, it is possible that Philoxenus also had access to, or some mediated knowledge of, those sources. Indeed, he may have had access to the same kind of synodal records as his close ally, Severus of Antioch. ${ }^{24}$ Considering that Adelphius had spent time in Edessa, it is also possible that Philoxenus had heard local stories about him during his own time in the city. 25

${ }^{17}$ Severus of Antioch, Letter to Entrechius of Anazarba, in Kmosko, Liber graduum, pp. ccxii-ccxxi. Severus refers to having seen the minutes and records of the synod at Comana.

${ }^{18}$ Timothy of Constantinople, On the reception of heretics, in Kmosko, Liber graduum, p. ccxxi. See Stewart, Working the earth, 52-68.

19 Photius, Bibliotheca 52 , Kmosko, Liber graduum, pp. cclii-cclxi at p. cclii.

${ }^{20}$ Gribomont suggests that 'Adelphians' was invented by heresiologists like 'Lampetians' and 'Marcianists', inspired by remarkable personalities: 'Le Dossier', 621.

21 Fitschen, Messalianismus, 93.

${ }^{22}$ André de Halleux, Philoxène de Mabbog: sa vie, ses écrits, sa théologie, Louvain 1963, 20-2; John Watt, 'Philoxenus and the Old Syriac version of Evagrius' Centuries', Oriens Christianus lxiv (1986), $65^{-81}$ at pp. $74^{-5}$. A recent article on Philoxenus' developing enthusiasm for Greek Christological polemics might complicate this view: Dana Viezure, 'Argumentative strategies in Philoxenus of Mabbug's correspondence: from the Syriac model to the Greek model', Hugoye xiii/ 2 (2010), 149-75.

23 David A. Michelson, The practical Christology of Philoxenos of Mabbug, Oxford 2014, 124-5; de Halleux, Philoxène, 1 79-82.

${ }_{24}$ Michelson, Practical Christology, 13-16, 33-6o; de Halleux, Philoxène, 76-92.

25 De Halleux, Philoxène, 22-30. 
In casting Adelphius as the founder of 'Messalianism', Philoxenus and others drew on the 'genealogical' approach of heresiology, a technique which typically enumerated the succession of teachers of a particular heresy in a perverse version of the philosophical diadoche, almost always leading back to a single founder figure. ${ }^{26}$ Identifying notorious heresies like 'Manicheism' and 'Marcionism' by the names of their founders conferred a useful unity on disparate groups and undermined the claim of their members to be 'Christians' by foregrounding their adherence to another leader. ${ }^{27}$ This naming technique is seen in Ephrem's Hymns against heresies; it also features at the end of the early fifth-century Syriac catalogue of heresies by Marutha of Maipherqat in a list of the fundamental elements required to write a proper history of heresy, including origins, region and founders' names. ${ }^{28}$

Philoxenus would have been familiar with the heresiological tradition in Syriac; among others, he clearly knew Ephrem's Hymns against heresies. ${ }^{29} \mathrm{He}$ can be seen practising the 'genealogical' approach to heresy himself in numerous polemics against Chalcedonian Christology. $3^{\circ}$ For instance, his brief Catalogue of all heresies linked the doctrines of Mani, Marcion and Eutyches in its very opening paragraph..$^{3^{1}}$ In a letter to Abu Ya'fur, he wrote a sweeping history of the identification and condemnation of heresies from Sabellius to Nestorius, studded with telling vivid anecdotes about heresiarchs of a kind that resemble the Adelphian episode. $3^{2}$

${ }^{26}$ Susanna Elm, 'The polemical use of genealogies: Jerome's classification of Pelagius and Evagrius Ponticus', Studia Patristica xxxiii (1997), 311-18; Hervé Inglebert, Interpretatio Christiana: les mutations des savoirs (cosmographie, géographie, ethnographie, histoire) dans l'antiquité chrétienne 30-63o après J.-C., Paris 2001, 413-14; Caroline Humfress, Orthodoxy and the courts in late antiquity, Oxford 2007, 21 7-23.

${ }^{27}$ Richard Lim, 'The nomen Manichaeorum and its uses in late antiquity', in Iricinschi and Zellentin, Heresy and identity, 143-67. See Ephrem, Hymns against heresies.

${ }^{28}$ Marutha of Maipherqat, On the heresies, ed. Arthur Vööbus, in The canons ascribed to Marutha of Maipherqat and related sources, CSCO cdxxxix / Scr. Syri cxci.22-7 at 27, trans. CSCO cdxl / Scr. Syri cxcii. $17^{-24}$ at 23 .

${ }^{29}$ Philoxenus wrote at least two florilegia which cite Ephrem's Hymns against heresies: see his Testimonies of the Fathers, ed. Maurice Brière and François Graffin, $P O$ xi/1 (1982), 58-129. See also the florilegium embedded in his Letter to the monks of Senun, ed. André de Halleux, 'Lettre aux moines de Senoun', CSCO ccxxxi / Scr. Syri xcviii.1-96, CSCO ccxxxii / Scr. Syri cic.1-80.

$3^{\circ}$ Lucas Van Rompay, 'Bardaisan and Mani in Philoxenus of Mabbog's mēmrē against Habbib', in Wout van Bekkum, Jan Willem Drijvers and Alex Klugkist (eds), Syriac polemics: studies in honour of Gerrit Jan Reinink, Leuven 2007, 77-90.

${ }^{31}$ Philoxenus, Catalogue of all heresies, ed. and trans. François Nau, 'Documents pour servir à l'histoire de l'église Nestorienne', $P O$ xiii/2 (1919), 248-9 at p. 248.

$3^{2}$ Philoxenus, Letter to Abu Ya'fur, ed. and trans. Paul Harb, 'Lettre de Philoxène de Mabbūg au phylarque Abū Ya'fūr de Hīrtā de Bētna'mān', Melto 3.1-2 (1967-8), $183^{-}$ 222. This letter has probably been interpolated with a section about the history of the Turks; for further bibliography see Michelson, 'A clavis', 298-9. 
Another genealogy of heresy culminating in Nestorius appeared in his second letter to the monks of Beth Gogal.33 After he had been exiled, in a letter to all the monks of the Orient, he described the history of the origins of the Novatians and Audians, before moving on to more recent heresies.34 The first fragment of this letter tantalisingly shares details with Socrates's Ecclesiastical history and Epiphanius' Panarion, showing that he may have had access to Greek histories of heresy, presumably in Syriac translation.

\section{Adelphius as an ascetic anti-exemplum}

Philoxenus described Adelphius almost incidentally as a 'Messalian' heresiarch, and the sources for this notion cannot easily be identified. By contrast, his construction of Adelphius as ascetic anti-exemplum is meticulous, detailed and vivid, and can be shown to draw on a rich tradition of ascetic instructional literature. In particular, Adelphius' downfall is presented as the reverse of an earlier salutary tale about a successful monk, sounding a warning note about the terrible consequences of arrogance and lack of persistence. The 'historical' Adelphius consequently recedes further from view.

Overall, the letter to Patricius contains nine stories which seem to draw on the apophthegmata, an amorphous body of sayings and stories about holy (and not so holy) monks in circulation in various languages in late antiquity. 35 Syriac translations of the apophthegmata are preserved in a number of manuscripts, the earliest of which date back to the sixth century, and 'Enanisho', who translated various monastic texts including apophthegmata into Syriac in the seventh century, made use of existing translations of these texts. $3^{6}$ Unfortunately, there is as yet no critical edition of

33 Philoxenus, Second letter to the monks of Beth Gogal, ed. and trans. André de Halleux in 'La Deuxième Lettre de Philoxène aux monastères du Beit Gaugal', Le Muséon xcvi (1983), $5^{-79}$ at paras $5^{-16}$, pp. 31-9. De Halleux (pp. 6-11) dates this letter to between 486 and 5 oo.

34 Philoxenus, Letter to the monks of the Orient, ed. and trans. Joseph Lebon, in 'Textes inédits de Philoxène de Mabboug', Le Muséon xliii (1930), 175-220. Lebon (p. 199) dates this letter to between $5^{20}$ and 5 22, after Philoxenus' exile to Philippopolis.

35 Graham Gould, The desert Fathers on monastic community, Oxford 1993, 1-25; Samuel Rubenson, 'The formation and re-formations of the sayings of the desert Fathers', Studia Patristica lv (2013), 5-22.

$3^{6}$ Sebastian Brock, 'Saints in Syriac: a little-tapped resource', Journal of Early Christian Studies xvi/2 (2008), 181-96 at pp. 195-6; Samuel Rubenson, 'The apophthegmata patrum in Syriac, Arabic and Ethiopic: status quaestionis', Parole de l'Orient xxxvi (201 1), 305-13 at pp. 307-9; Peter Toth, 'Syriac versions of the "Historia monachorum in Aegypto": a preliminary investigation on the basis of the first chapter', Oriens Christianus xciv (2010), 58-104. 
the Syriac sayings, and so we must rely on Bedjan and Budge's compilations from late manuscripts, supplemented by important recent work on earlier manuscripts, to identify possible echoes of the sayings in Philoxenus. 37 Philoxenus seems to allude to both the oral and written transmission of sayings in his letter. In paragraph 36 , he writes that 'I am going to tell you as an example of the sayings that I have heard ( $\Delta, \mathbf{s})$ on the subject of certain saints', and at paragraphs 19 and $5^{2}$ he writes that 'I have heard (s) a saying of the saint'; however, at paragraph 53 he introduces a story by saying that the Fathers 'have written (دs) on these subjects', and adduces a particular example by exclaiming: 'See what is written (دג) on the subject of a saint!' René Lavenant suggests that his abbreviated reportage of some sayings reveals him to be recalling them from memory. In the case of the story about Adelphius, it is possible that Philoxenus - or an intermediate source - actually engaged in some creative expansion or amalgamation of different sayings. $3^{8}$

The sheer number of allusions to the apophthegmata in the letter to Patricius is striking, for Philoxenus rarely alluded to them elsewhere in his surviving works. 39 Of course, this pattern can be explained by the hortatory thrust of most of his letters, which aimed to shore up his correspondents' miaphysite faith and condemn their 'heretical' Chalcedonian opponents; only a few, shorter letters provided direct guidance on matters of ascetic practice, where the examples of the apophthegmata were germane. $4^{\circ}$ In the letter to Patricius, allusions to the apophthegmata cluster at particular points in his argument. In paragraph 19, Philoxenus cited three sayings to teach lessons about practices such as hospitality, solitude and seclusion in one's cell. In paragraphs 37,38 and 39, he cited three sayings - attributed to Poemen and Benjamin - to teach the lesson of fleeing important people. In paragraphs 52 and 53, he reported a further two sayings which taught that the monk should consider himself a sinner and act with consummate humility, the latter of which included an exemplary story of an anonymous monk who refused to accept a Satanic vision of Christ:

37 Paul Bedjan, Acta martyrum et sanctorum, Paris 1897, vii; Ernest Wallis Budge, The book of paradise, London 1904; Bo Holmberg, 'The Syriac collection of apophthegmata patrum in ms Sin. syr. 46', Studia Patristica lv (2013), 35-57.

$3^{8}$ Lavenant, 'La Lettre', 785 n. 93 .

39 It is unlikely that the ascriptions to Philoxenus of commentaries on apophthegmata in Arabic and Ethiopic manuscripts are genuine: de Halleux, Philoxène, 291-3; Michelson, 'A clavis', 315 .

$4^{\circ}$ Philoxenus, Letter to a lawyer-turned-monk tempted by Satan, ed. and trans. François Graffin, in 'Une Lettre inédite de Philoxène de Mabboug à un avocat, devenu moine, tenté par Satan', L'Orient Syrien v (1960), 183-96 at p. 192 (paragraph 18) refers to an as yet unidentified saying. 
Here is what is written on the subject of one of the holy men: Satan came and stood before him in the form of an angel (כזי) from whom shone forth a great light. Now the saint, as soon as he saw it, shut his eyes. And Satan said to him, 'Open your eyes and see the light, for this I have come to show you the light.' But [the saint] held firm and did not want to open his eyes; and Satan said to him, 'I am Christ and I have come to appear to you.' He responded, 'I do not want to see Christ here, but in his place.' $4^{1}$

Lavenant noted that this story has parallels in various collections of apophthegmata, including a Syriac saying that recounts the story of an anonymous old man labouring in his cell, striving against demons, to whom Satan appeared 'in the form of a man', and declared 'I am Christ'; the old man immediately shut his eyes and mocked him, and when asked by Satan why he had shut his eyes, answered: 'I do not desire to see Christ here.' The devil duly departed and did not appear again. ${ }^{42}$ Recent work on earlier manuscripts of the Syriac apophthegmata than those used by Bedjan and Budge allows us to establish that this particular story is preserved in almost identical form in Ms Sinai syr. 46 , providing concrete evidence for the circulation of the story in Syriac close to Philoxenus' time. 43

Lavenant did not note that Philoxenus' story also evinces parallels with another saying, only so far attested in later Syriac manuscripts, which provides some of the variant details. In this episode, Satan appeared to an anonymous old man 'in the form of an angel of light', and said 'I am the angel Gabriel, and I have been sent to you.' The holy man said to him: 'Surely you have been sent to another, because I am a sinner'; Satan again disappeared, routed.44 Both sayings play on Paul's famous comment at 2 Corinthians xi.14, 'for Satan disguises himself as an angel

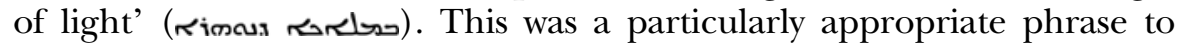
evoke in describing a heresiarch, as its bigger context alluded to the dangers of false apostles disguising themselves as apostles of Christ, and thus yoked together false teachers and leaders with Satanic illusions.

$4^{1}$ Philoxenus, Letter to Patricius 53, Lavenant, 'La Lettre', 800-1.

$4^{2}$ Lavenant ('La Lettre', 801 n. 19), cites parallels with apophthegmata edited in various collections: Paul Bedjan, Acta martyrum, vii. 716 (recte 716-17); PL lxxiii. 965; François Nau, 'Histoires des solitaires Egyptiens', Revue de l'Orient Chrétien xvii (1912), 206; xviii (1913), 144. He does not cite Budge, Book of paradise, 824-5. The two relevant apophthegmata from the Greek systematic collection $(15.87 ; 15.89)$ can now be consulted in the up-to-date edition by Jean-Claude Guy, Les Apophtegmes des pères, Paris 2003, 343-3.

43 This saying can be found in Sinai syr. 46 , fo. 4 ov. The apophthegmata in Sinai syr. $4^{6}$ are helpfully tabulated and correlated with those in Bedjan, Budge and the Greek collections by Holmberg in 'The Syriac collection of apophthegmata patrum', 41-57.

44 Bedjan, Acta martyrum vii. $714^{-1} 5$. This story does not appear in Sinai syr. 46 . 
Later in his letter, in the cautionary story of Adelphius' downfall in paragraph 110 , Philoxenus referred back to the earlier salutary story, and in lamenting Adelphius' ignorance of the apotropaically effective works of the humble monk, he powerfully commended their value to Patricius:

then Satan found [Adelphius] lacking in the science of practice, and coming he appeared to him and showed himself to Adelphius under the likeness of a light

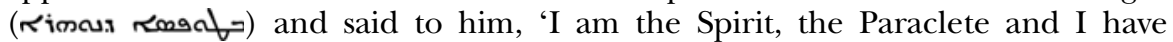
been sent to you by Christ as a reward for your labours in order to render you worthy of seeing the contemplations which you desire, and to give you impassibility and rest from your labours.' And in return [Satan] asked him for worship $(\kappa h i-\infty)$. And Adelphius, like a fool, not well practised in the art of combat, did not know the words of the monk which I reported above, 'I do not want to see Christ in the here and now, but I pray to see him in his world', which would have made him, the demon trickster, disappear at once from his presence, as was the case for the saint; Adelphius, then, desiring the glory of extraordinary things, worshipped him $(\infty)$ ( $)$ and accepted his coming. [Satan] then took him into his power and, in the place of divine contemplations, filled him with demonic hallucinations, and he made him stop completely his earlier labours and held him suspended in the hope of impassibility, as if he had no more need of labours, nor of bodily mortifications, nor of the struggle against desires. 45

The story of Adelphius looks like a mirror image of the tale which Philoxenus had earlier related about the anonymous monk, suggesting some manipulation of the tradition. However, rather than demonstrating a reverse invention on the part of Philoxenus, another possible source for it can be found among the Syriac versions of Palladius' Lausiac history. Draguet's delicate work on this complex material had not been published before Lavenant's preparation of his edition of Philoxenus, which explains why he did not note these parallels..$^{6}$ A cautionary tale about a monk who was tricked by a Satanic vision survives only in a Syriac fragment of the Lausiac history, not in any Greek version, and offers a striking parallel to Adelphius:

One night Satan appeared to Eucarpius in the form of an angel of light

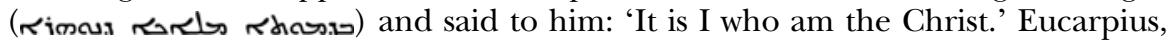
then, when he saw him, thought that the vision was true. He fell down, worshipped him (m) , and said to him: 'What does my Lord command his servant?' ... Eucarpius, then, exalted himself still more and became proud in spirit. He was convinced and believed in the deceiver's lie, for his reason was taken away from him; and he was harmed in his mind as soon as he worshipped the adversary. 47

45 Philoxenus, Letter to Patricius 1 10, Lavenant, 'La Lettre', 852-5.

$4^{6}$ René Draguet, Les Formes syriaques de la matière de l'Historie lausiaque, Leuven 1978 , CSCO ccclxxxix-ccclxc.398-9 / Scr. Syri clxix-clxx.1 $73-4$.

47 Fragment HL 73, ed. René Draguet, CSCO cccxcviii.368-72, with comments on this episode at 364 ; trans. CSCO cccic.239-41. 
In its structure and scriptural allusions, Palladius' story about Eucarpius tallies with Philoxenus' account of Adelphius being deceived by the disguised Satan. In Palladius, the devil appears 'in the form of an angel of light', in Philoxenus, 'in the likeness of a light', both in keeping with 2 Cor. xi. 14 . Eucarpius and Adelphius both accepted their visions by worshipping Satan, using the same verb for 'worship' ( scene in the Gospels (Matthew iv.9; Luke iv.7), where the devil promised Christ power and glory if he worshipped him. The end result of their obedience to Satan was a kind of diabolical maddening: Eucarpius was deranged while Adelphius was filled with demonic hallucinations.

There may be a second allusion to one of the Syriac versions of the Lausiac history in the very next paragraph of Philoxenus' letter to Patricius, describing the downfall of the fourth-century monk Asuna. Asuna was tricked by Satan into leaving his cell, taken to a mountain, shown a shape of chariot and horses and told that 'God has sent to seek you to lift you up like Elijah on the chariot.' He went to mount the chariot, but the fantasy dissolved and he was thrown down and killed. This tall tale resembles a demonic merkabah episode in Syriac Palladius where a monk variously called Elijah or Valens was deceived and deranged by a Satanic vision in which demons appeared as angels bearing lamps and on a fiery chariot, accompanied by Satan 'in the form of Christ'

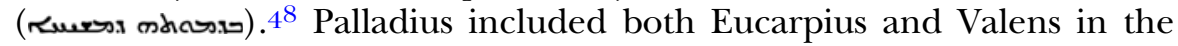
list of monkish anti-exempla about whom he, Evagrius, and Albanus had sought further enlightenment in a visit to the desert Fathers Cronius and Paphnutius.49 It is suggestive that Philoxenus narrated in quick succession two stories which were also yoked together by Palladius.

Although the history of the composition, translation and transmission of the Greek and Syriac versions of the Lausiac history is extremely complicated and still debated, it can be surmised that some version of this text was available to Philoxenus, since the earliest Syriac manuscripts of it date to the sixth century, and since he also seems to have alluded to a Palladian episode in another letter. $5^{\circ}$ However, it is also possible that Philoxenus and Palladius both made use of stories in more general

$4^{8}$ Palladius, Lausiac history $25^{\text {A.4 }}{ }^{-5}$, version $\mathrm{R}_{1}$, ed. and trans. Draguet, CSCO ccciic. 213-5; cccic.145-8. See Alexander Golitzin, "“The demons suggest an illusion of God's glory in a form": controversy over the divine body in some late fourth, early fifth century monastic literature', Studia Monastica xliv (2002), 13-43, esp. pp. 33-7.

49 Palladius, Lausiac history $47 \mathrm{~B}_{3}$, ed. and trans. in Draguet, CSCO ccciic.3o8; cccic.201.

$5^{\circ}$ Philoxenus, Letter to a lawyer-turned-monk, 183-96 at p. 196 (paragraph 26) narrates a story about the devil sending a fire on to the mat on which Macarius was praying in his cell which resembles an anecdote about Macarius of Alexandria found in a Syriac version of Palladius' Lausiac history 18.13, ed. and trans. Draguet, CSCO ccclxxxix.144-5; cccxc.102. 
circulation, whether oral or written, rather than Philoxenus borrowing directly from Palladius. Here, another possible common source for Philoxenus and Palladius was the cuvre of the fourth-century Egyptian ascetic superstar Evagrius of Pontus, who had warned monks about demons appearing to them in the form of angels and flattering them into worshipping them and abandoning their ascetic labours. Proud monks who thought themselves worthy of a direct and sensible vision of God were particularly susceptible to this ploy, as he explained in a treatise offering guidance on the ascetic life to Eulogius:

So then, when the heart resounds with the glory of the thoughts and there is no resistance, he will not escape madness in the secret of his mental faculties, for his ruling faculty risks being shaken loose from its senses, either through dreams which are given credence, or through forms that take shape during vigils, or through visions seen in a change of light. For 'Satan himself takes on the form of an angel of light' [2 Cor. xi.14] to deceive us: he indicates perhaps that he will grant charisms so that you will fall down and worship him [Matt. iv.9] or he proclaims that he will take you up as another Elias; or he promises to sanctify some of those who having received the faith missed the mark regarding the truth and became mentally deranged. $5^{1}$

It is notable that, in this warning, Evagrius, like Palladius and Philoxenus, yoked together scriptural allusions to Paul on Satan appearing as an angel of light, to the Gospel account of Satan's temptations of Christ, and to Elias's ascent. Scholars have long debated how thorough-going and sustained Philoxenus' adherence to Evagrian theology and ascetic ideology was, but it now seems clear that Philoxenus was the heir to a particular strand of the Syriac reception of Evagrius. $5^{2}$ He made considerable use of Evagrian texts and ideas across his works, but they are particularly numerous and prominent in his letter to Patricius, which is in part an attempt to provide an outline of what Evagrian ascetic practice should involve. 53 We should also note that Palladius had himself been a disciple of Evagrius, and clearly knew many of his works, even alluding to them in his own, meaning that there is considerably inter-penetration and

${ }^{11}$ Evagrius, To Eulogius 34, $P G$ lxxix.1 137-40, adapted translation from Robert Sinkewicz, Evagrius of Pontus: the Greek ascetic corpus, Oxford 2003, 12-59; his translation of the longer Greek recension of the text is based on a variety of editions and manuscripts. On Syriac versions of this text see J. Muyldermans, Evagriana Syriaca: textes inédits du British Museum et de la Vaticane, Leuven 1952, $4^{6-54}$.

$5^{2}$ P. Harb, 'L'Attitude de Philoxène de Mabboug à l'égard de la spiritualité "savant" d'Évagre le Pontique', in François Graffin (ed.), Mémorial G. Khouri-Sarkis, Leuven 1969, 135-55; Watt, 'Philoxenus and Evagrius' Centuries', $65^{-81}$; Robin Darling Young, 'The influence of Evagrius of Pontus', in Robin Darling Young and Monica Blanchard (eds), To train his soul in books: Syriac asceticism in early Christianity, Washington, DC 2011 , 157-76; Michelson, Practical Christology, 82-1 12.

Michelson, Practical Christology, 109-11. 
theological and ascetic resonances between their works; if Philoxenus had read a Syriac version of Palladius, he would have imbibed Evagrius through it. 54

\section{Adelphius as an epitome of 'Messalianism'}

Although it is not possible to pin down a single source for Philoxenus' story about Adelphius, nor to establish if the apparent blending of different sources was his own or belonged to an intermediate, lost text, there is a clear 'family resemblance' between anecdotes from Philoxenus, the apophthegmata, Palladius and Evagrius. These tales often seem to have shifted slightly in the telling to suit particular audiences and polemical needs, and Philoxenus' story likewise displays some significant alterations and emphases which both further demonised the Messalians, and tackled theological ideas which were pressing in his own day.

One of the striking features of Philoxenus' story about Adelphius is that Satan presented himself to the hapless monk as a vision of the 'Holy Spirit and Paraclete', not as a vision of Christ; this differs from the various traditions discussed above about the devil coming in divine disguise to tempt monks, where he consistently appeared as an angel or as Christ. It seems likely that Philoxenus' variation on this trope was not incidental, but reflected long-standing anxieties about the special relationship with the Holy Spirit claimed by Messalians. This was an important component of the Messalian beliefs which Adelphius was apparently tricked into revealing at the Synod of Antioch, reported by Theodoret in a way that suggests that he was drawing on an existing list.55 Adelphius apparently claimed that every man was born with an indwelling demon against which baptism had no efficacy and which could only be expelled by intensive prayer. After this exorcism, and in the same way that the demon had exited, the

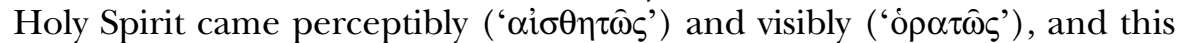
in turn freed the body from the impulse of the passions and the soul from its inclinations to the worse. Such a fortunate recipient of the Holy Spirit also received the gift of foresight, and was able to behold the Trinity. $5^{6}$ In his Compendium, Theodoret provided a more precise account of this last capacity: 'to see the Father and the Son and the Holy

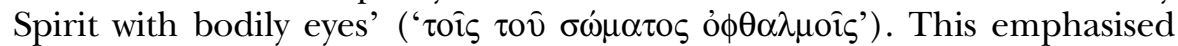

54 René Draguet, 'L'Histoires Lausiaque: une oeuvre écrite dans l'esprit d'Évagre', Revue d'histoire ecclésiastique xli (1946), 321-64; (1947), 5-49; Jeremy Driscoll, Steps to spiritual perfection: studies on spiritual progress in Evagrius Ponticus, Mahwah 2005, 94-122.

55 Stewart, Working the earth, 25-9, 32-4, 52-64.

$5^{6}$ Theodoret, Ecclesiastical history 4.11, ed. and trans. Canivet, SC dxxx. 226, and Compendium 4.1 1, Kmosko, Liber graduum, pp. cxcvi-cxcviii. 
that the Messalians claimed to be able to see all the divine persons in physical and bodily, not intellectual or metaphorical, terms.

Philoxenus' description of Adelphius is thus in some respects a biographically inflected epitome of 'Messalian' teaching. It also reflects some of his broader theological preoccupations. One context against which to view it is the anthropomorphite controversy of the late fourth century, revolving around questions of the visibility of the persons of God.57 The later accusation of iconoclasm made against Philoxenus may have its roots in his apparent hostility to anthropomorphic images of Christ and the angels..$^{8}$ Later in the letter to Patricius, Philoxenus clearly explained that humans could no longer expect to receive direct visions of God, emphasising the disjuncture between the previous dispensation of the Old Testament, in which God spoke with and 'revealed himself' (Rom shos) to man, and the present, when he no longer spoke to anyone in 'bodily' form (מoriva).59 The Adelphius anecdote may also reflect something of Philoxenus' own pneumatology. He rejected the possibility of receiving perceptible visitations of the Holy Spirit, developing the notion that the Holy Spirit lived in the souls of the faithful like a light in the pupil of a human eye and was thus integral to the process of seeing rather than a mere external object of sight. ${ }^{60}$

As well as ridiculing the very idea that a monk might see the Holy Spirit with his bodily eyes, Philoxenus' story about Adelphius provided a vivid aetiology for other 'Messalian' behaviours. The claim of the Messalians to have received the Holy Spirit was embedded in their preferred term for themselves as 'spiritual ones' (' $\pi v \varepsilon v \mu \alpha \tau \iota \kappa o i ́) .{ }^{61}$ In anti-Messalian texts of the fifth century onwards, one of the group's other names - 'pos-

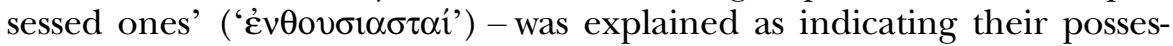
sion not by the Holy Spirit, but by a demon: Theodoret remarked that "They are called "possessed ones", receiving the energy of some demon and taking this to be the coming of the Holy Spirit. ${ }^{62}$ He suggested that a demon had stirred the Messalians to a frenzy: 'Having been deceived by the demon which makes them frenzied, they say they see revelations, and they attempt to foretell the things to come: they are convicted as frauds by the facts. ${ }^{6} 63$ Timothy of Constantinople expanded on this:

57 Golitzin, “"The demons suggest an illusion of God's glory in a form"'.

$5^{8}$ Glen Peers, Subtle bodies: representing angels in Byzantium, Berkeley 2001, 71-4.

59 Philoxenus, Letter to Patricius, 12 1-2, Lavenant, 'La Lettre', 862-5.

60 Roberta Chesnut, Three monophysite Christologies: Severus of Antioch, Philoxenus of Mabbug, and Jacob of Sarug, London 1976, 94-5. Sebastian Brock provides a translation of a fragmentary text of Philoxenus which deals with the indwelling of the Holy Spirit: The Syriac Fathers on prayer and the spiritual life, Kalamazoo 1987, 106-27. See also Michelson, 'A clavis', 307-8.

61 Theodoret, Compendium 4.1 1, Kmosko, Liber graduum, pp. cxcviii.

62 Theodoret Ecclesiastical history 4.1 1, Canivet, SC dxxx.222.

63 Theodoret, Compendium 4.1 1, Kmosko, Liber graduum, p. cxcviii. 
They say that after what is called by them apatheia, they give themselves over to much sleep, and the dreams which occur by the inspiration of the evil demon, energizing them, they herald as prophecies; and they teach that these things are to be believed as inspired by the Holy Spirit. These possessions they regard and name as holy; they are deceiving and deceived. ${ }^{64}$

While the Messalians were said to have believed themselves to be full of the Holy Spirit, those writing against them argued that they were in fact possessed, energised and maddened by a demon. The Messalians' claims of special experience and powers were thus reversed by their opponents, who provided another explanation for these phenomena: any powers or sensible experiences that they had, or claimed to have, were in fact provided by demons, including their claims, on achieving a state of apatheia, to prophesy. Indeed, even the prophetic revelations which they believed that they had received were illusory. The idea of demonic maddening, as old as tragedy but still current in the language of demonic seizure, was extended to their apparently fanciful demon-fighting: 'And they undertake many deeds of a fevered brain. For suddenly they leap up and act hot-headedly, jumping over demons, and act as if their fingers were arrows, contending that they shoot the demons.' ${ }^{5}$ The suggestion that the Messalians' demon-fighting was in fact a fantastical illusion propelled by a very real demonic madness was both damning and neatly reflexive: the Messalians who claimed to have experienced the departure of their indwelling demons (in which their opponents did not believe) actually proved, in an ironic twist, that they had in fact been possessed by other demons (in which their opponents did believe).

To accuse one's opponents of being inspired by Satan and his demons was a rhetorical ploy common to the earliest heresiological literature, as well as to anti-pagan and anti-Jewish works. ${ }^{66}$ For example, Ephrem structured the whole of the first of his Hymns against heresies around the notion that 'the evil one' and 'the envious one' - that is, Satan - was responsible for the evils of the heresiarchs Bardaisan, Marcion and Mani. ${ }^{67}$ In the opening preamble to his catalogue of heresies, Marutha of Maipherqat wrote that Satan 'spewed out factions and divisions and made contentions

64 Timothy of Constantinople, On the reception 14, Kmosko, Liber graduum, ccvxii. The connection between dreaming, deceit and demons is of course well-established: Patricia Cox Miller, Dreams in late antiquity: studies in the imagination of a culture, Princeton 1994, 63-5. $\quad{ }_{35}$ Theodoret, Compendium 4.11, Kmosko, Liber graduum, ccxxvi. ${ }_{66}$ Elaine Pagels, Origin of Satan: how Christians demonized Jews, pagans and heretics, New York 1995, ch. vi; Sophie Lunn-Rockliffe, 'Diabolical motivations: the devil in ecclesiastical histories from Eusebius to Evagrius', in Geoffrey Greatrex and Hugh Elton (eds), Shifting genres in late antiquity, Farnham 2015, $119-31$.

${ }_{7}$ Ephrem, Hymns against heresies 1, ed. Beck, CSCO clxix / Scr. Syri lxxvi.1-5. See Phil Botha, 'The textual strategy of Ephrem the Syrian's Contra haereses $I$, Acta Patristica et Byzantina xv (2004), 57-75. 
and quarrels and brewed many evil things through the multitude of heresies which he brought about over the church' ${ }^{68}$ Philoxenus frequently alluded to this idea of diabolically inspired heresy in works pugnaciously attacking Chalcedonian Christology and exhorting followers, mostly monks, to stand firm in their miaphysite faith. A few representative examples will give a flavour of his tone. In a series of anathemas, he characterised his opponent as 'filled with the malice of the devil', 'an embodied devil', and one in whom 'the evil spirit dwells'; 69 in the opening of another letter, he cast heretics as 'servants of Satan' and 'temples of demons' $7^{\circ} \mathrm{He}$ compared heretics 'in whom Satan works and who are the vessels of his ministry' to the serpent in Eden as a justification for anathematisation of heretics, even after their death, $7^{1}$ and described Arius as an implicitly Satanic 'serpent'. $7^{2} \mathrm{He}$ argued that the sacraments and altars of the 'Nestorians' were not sanctified by the Holy Spirit, but polluted by the spirit of Satan.73

The Satanic dimension of Philoxenus' story about Adelphius thus followed broader rhetorical strategies of 'demonisation'. It was also very appropriate for the leader of a group whose members thought that they were inspired by the Holy Spirit. Such 'enthusiastic' Christians were particularly vulnerable to the reversal of their claim to divine inspiration, and were regularly accused of being deceived and inspired or possessed by a demon or the devil, as seen in the account by Apollinarius of Hierapolis, preserved in Eusebius, of the origins of the so-called 'Phrygian heresy' (otherwise labelled as 'Montanism').74 In this, Montanus, a recent convert to Christianity, gave 'the adversary' (the devil) an opportunity against him in his ambitions for leadership, and began to rave ecstatically and prophesy in tongues. Those who heard responded in two ways. Some rebuked him 'as one that was possessed, and under the control of a demon and led by a deceitful spirit' and forbade him from talking. Others imagined themselves 'possessed of the Holy Spirit and of a prophetic gift' and followed Montanus. There follows a description of the devil stirring up two women (Priscilla and Maximilla) and filling them with a false spirit so that they prophesied

68 Marutha of Maipherqat, On the heresies, ed. Vööbus, CSCO cdxxxix.

69 Philoxenus, First letter to monks of Beth Gogal, ed. Arthur Vaschalde, in Three letters of Philoxenos, bishop of Mabbogh (485-519), Rome $1902,14^{6-62}$ at pp. ${ }_{155^{-7}}$, trans. $105^{-}$ 17 at pp. $112-14$.

$7^{\circ}$ Philoxenus, Letter to the monks of Senun, ed. de Halleux, CSCO ccxxxi / Scr. Syri xcviii. $1-96$ at 3, trans. CSCO ccxxxii / Scr. Syri ic.1-8o at 2. See Michelson, Practical Christology, $175^{-6 .}$

${ }^{71}$ Philoxenus, Letter to Maron of Anazarbus, ed. J. Lebon, in 'Textes inédits de Philoxène de Mabboug', Le Muséon xliii (1930), 17-84 at pp. $5^{1-2}$, trans. at p. 75 .

$7^{2}$ Philoxenus, Letter to Abu Ya'fur, ed. and trans. Harb, $189 . \quad 73$ Ibid. 220.

74 Eusebius, Ecclesiastical history 5.16.1-22, ed. Eduard Schwarz, Die Kirchengeschichte, GCS, Leipzig 1903, ii/1, 458-68. 
and reviled the universal Church. As we have seen, it was a common accusation that the Messalians were inspired by Satan, but thought themselves to be filled with the Holy Spirit. Such a notion was epitomised by Philoxenus' story about the 'founder' and 'leader' of Messalianism himself giving in to a Satanic vision of the Holy Spirit which filled him with demonic hallucinations and put him under Satan's power. In casting Adelphius as the demonically deluded founder of Messalianism, Philoxenus was deploying a rhetorical strategy which he practised regularly against other doctrinal opponents, especially dyophysites.

In his story about Adelphius, Philoxenus interwove tales from the Egyptian monastic milieu with demonic insinuations typical of heresiological literature to provide a cautionary tale about the founder of 'Messalianism'. In his account, Adelphius was a proud and vain monk who naively accepted a diabolical embassy as a sensible vision of the Holy Spirit, and was thus conquered by Satan and received demonic hallucinations in return, much as his followers' claims to intimate relations with the Holy Spirit and special powers thereby acquired were dismissed as demonically inspired madness. Philoxenus clearly had some knowledge and understanding of stories about the Messalians, such that he could identify Adelphius as its heresiarch, and attribute to Adelphius a personal narrative of ascetic failure which epitomised the hostile accounts of his group's beliefs and practices in circulation. He also knew something about the afterlife of the group. If Adelphius had spent time in Edessa and had garnered large numbers of monastic supporters there before their expulsion and banishment to Iconium, then Philoxenus, who had also spent considerable time in the city, might have had access to lingering local memories about them. It is also possible that Philoxenus chose to write about Adelphius and Asuna as individuals with a particularly piquant local relevance for his correspondent, Patricius: both were said to have been monks in Edessa, where Patricius was currently pursuing his own ascetic ambitions. Philoxenus' vivid anecdote did not mark the end of the invention of heresiarchs for the Messalians. In the later, shorter Syriac recension of the letter to Patricius, the name 'Adelphius' has been replaced by the name fals; this

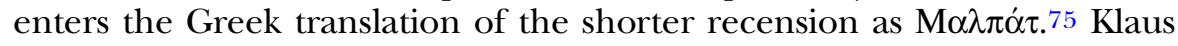
Fitschen suggests that the substitution may be a confused version of 'Lampetius', mentioned above as a more recently troublesome presbyter

75 The Syriac text of the shorter recension has not yet been edited, but can be found in two manuscripts dated between the eighth and tenth centuries. See Ms Vat. syr. 125,

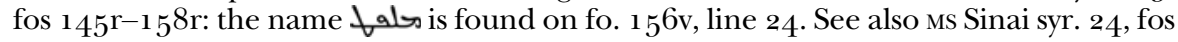
$147 \mathrm{v}-164 \mathrm{v}$. See Kessel, 'Sinai syr. 24', and Sebastian Brock, 'Syriac into Greek at Mar Saba: the translation of St Isaac the Syrian', in Joseph Patrich (ed.), The Sabaite heritage in the Orthodox Church from the fifth century to the present, Leuven 2001, 201-8. For the

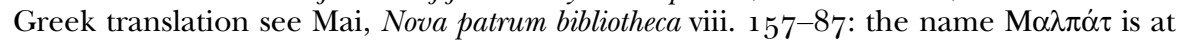
p. 184 . 
condemned according to Severus for 'Adelphianism' at a church council at Comana in the mid-fifth century. $7^{6}$ Thus the genealogy of a demonised heresy continued to accumulate and shift, re-naming itself, and rewriting its foundation story as it went.

Jnl of Ecclesiastical History, Vol. 68, No. 3, July 20I 7. (C) Cambridge University Press 2017 doi:10.1017/SoO22046917000781

\section{The Eusebius Essay Prize The World Christianities Essay Prize}

The Journal now offers two annual essay prizes of $£_{5}$ oo apiece. The Eusebius Essay Prize is awarded to the best essay submitted on a subject connected with any aspect of early Christian history, broadly understood as including the first seven centuries AD/CE. Scholars of any relevant discipline (theology, classics, late antique studies, Middle Eastern Studies etc.) are encouraged to enter the competition. The new World Christianities Essay Prize will be awarded to the best essay submitted on any aspect of the history of Christianity beyond Europe and North America since the year 70o, and is likewise open to scholars of any relevant discipline. Both competitions are open to scholars regardless of seniority, although submissions from junior scholars are particularly welcomed. Submissions for either prize should not exceed 8,ooo words, including footnotes. Submissions should be made by 30 September 2017 (for the Eusebius prize) or 31 March 2018 (for the World Christianities prize): the winning essays will be published in the Journal, probably in the numbers appearing in July 2018 (Eusebius) and January 2019 (World Christianities). Other submissions entered into the competition may also be recommended for publication. The editors reserve the right not to award either prize if no essay of sufficient quality is submitted. All essays should be sent by email attachment (with the name of the relevant prize in the subject line), prepared to Journal style, to Mrs Mandy Barker at jeh@robinson.cam.ac.uk

${ }^{6}$ Fitschen, Messalianismus, 26, 92, 280. 